\title{
Vulnerability as Expected Poverty in Rural India ${ }^{1}$
}

\author{
Raghbendra Jha ${ }^{1}$, Woojin Kang ${ }^{2}$, Hari K. Nagarajan ${ }^{3}$ and Kailash C. Pradhan ${ }^{3}$ \\ ${ }^{1}$ Australian National University, Canberra, Australia, corresponding author r.jha@anu.edu.au \\ ${ }^{2}$ Korea Development Institute and Australian National University, Canberra, Australia \\ ${ }^{3}$ National Council for Applied Economic Research, New Delhi, India
}

\begin{abstract}
Using a unique panel data for rural India for the periods 1999 and 2006 this paper models vulnerability to poverty. We quantify household vulnerability in rural India in 1999 and 2006, investigate the determinants of ex post poverty as well as ex ante vulnerability, assess the role of ex ante vulnerability on poverty shift during the sample periods (i.e. movement into/out of poverty) and finally, examine how the effects of the determinants of vulnerability vary at different points across the vulnerability distribution. We conclude that over time economic growth has reduced the incidence of poverty. Although chronic poverty is relatively small the high incidence of transient poverty underscores the importance of covariate and idiosyncratic shocks. Household vulnerability across the distribution of such vulnerability is also investigated. A number of factors affect such vulnerability across this distribution. Thus the paper isolates a number of characteristics of households and policy variables which can be targeted to reduce the incidence of vulnerability in rural India.
\end{abstract}

JEL Classification Code: C23, C25, C31, I32

Keywords : Vulnerability, Poverty, Covariate and Idiosyncratic shocks, REDS data, India.

Address all correspondence to:

Prof. Raghbendra Jha, ASARC,

Arndt-Corden Dept of Economics,

H.C. Coombs Building (09)

Australian National University,

Canberra, ACT 0200, Australia

Phone: + 6126125 2683, Fax: + 6126125 0443,

Email: r.jha@anu.edu.au

\footnotetext{
${ }^{1}$ This paper is part of the IDRC-NCAER research program on "Building Policy Research Capacity for Rural Governance and Growth in India" (grant number 105223). We wish to thank Hans Binswanger and Andrew Foster for comments on earlier drafts. Expert assistance provided by Sudhir Kumar Singh is gratefully acknowledged. The usual caveat applies.
} 


\section{Introduction}

Driven by the fact that a variety of risks often cause high fluctuations in a households' income or consumption a growing body of research has recently shed light on the study of vulnerability. In developing countries where agriculture is the mainstay of a majority of the population this volatility of income is more apparent in rural areas where a household's main income source is agricultural activity. In several of these cases rural households face incomplete credit and insurance markets, if not their complete absence. Although households try to prevent those risks ex ante and/or attempt to reduce the degree of (downside) fluctuation ex post, such livelihood strategies often do not perfectly protect people (Townsend, 1994; Udry, 1990; Dercon, 2005). Besides, for households lacking instruments to manage risks, vulnerability caused by risks is likely to translate into poverty.

Vulnerability is risk specific and a forward looking concept that illustrates future outcome whereas poverty describes past or current status. Therefore, poverty and vulnerability they are close but distinct concepts. One definition of ex ante vulnerability is 'Vulnerability as Expected Poverty’ (VEP- e.g. Chaudhuri, Jalan and Suryahadi, 2002; Pritchett, Suryahadi and Sumarto, 2000). For the precise assessment of vulnerability, one needs to use panel data which is seldom available in developing countries. Such a VEP measure has the advantage that it serves as a measure of expected poverty. Further, if the expected poor actually turn out to be poor in a subsequent time period they can be identified as chronically poor. Thus this paper enables us to explore the linkage between chronic poverty and vulnerability. Thus this is a generalization of the existing literature because the two existing popular approaches to chronic poverty do not incorporate vulnerability (e.g. Barrientos, 2007; CPRC 2008; McCulloch and Calandrino, 2003). ${ }^{2}$ Furthermore, the link between chronic poverty and

\footnotetext{
${ }^{2}$ Two broad methods of chronic poverty in literature are (i) the spells approach focusing on poverty transition (Gaiha and Deolalikar, 1993) and (ii) the component approach distinguishing permanent component of income from fluctuating component (Ravallion, 1988; Jalan and Ravallion, 2001)
} 
vulnerability has rarely been empirically explored. The present study is motivated by such a potential association between vulnerability and poverty dynamics, and contributes to this research to some extent, by investigating the impact of ex ante vulnerability on ex post poverty dynamics in rural India (i.e. whether vulnerability generates poverty trap).

In this paper we analyse VEP in rural India using a new data set, drawing on two rounds of panel data. Specifically, we attempt to (i) quantify household vulnerability in rural India in 1999 and 2006, (ii) investigate the determinants of ex post poverty as well as ex ante vulnerability, (iii) assess the role of ex ante vulnerability on poverty shift during the sample periods (i.e. movement into/out of poverty) and finally, iv) examine how the effects of the determinants of vulnerability vary at different points across the vulnerability distribution.

To address these research objectives the plan of this paper is as follows: we briefly describe the data sets used in the section II, followed by the discussion of the model specifications and the econometric methodology in section 3. Section IV presents and discusses the results of our estimation. Section V offers policy implications and conclusion.

\section{Data}

The present paper draws upon the ARIS/REDS survey of the NCAER. Being designed to be a nationally representative multi-purpose rural household and village surveys, REDS was first collected in 1971 and subsequent rounds were conducted in 1982, 1999 and 2006. The survey is divided into three components (listing, household and village questionnaire) and collects detailed household and village information spread across various states in rural India.

The listing component provides information on a number of important household characteristic such as household income and demographics. The household survey collects information with respect to individual and household characteristics, education, labour participation, detailed incomes by sources, household consumption expenditure, agricultural 
activities, land and various asset ownership. The village survey provides economic and political structure, infrastructure, provision of public goods such as schools, health service, financial institutions and other social services.

The numbers of sample households in 1999 and 2006 surveys are 7474 and 8659 respectively, of which 5883 households were interviewed in both rounds. To analyse household vulnerability, we use the 5886 households that form the panel. The final sample size of used in the present study are 4743 (year 1999 observations of panel component), 4503 (year 2006 observations of panel components) and 3618 (panel) households due to missing observations in some variables. The summary statistics are given in Appendix table 2.

\section{Methodology}

\section{(a) Measuring Vulnerability ${ }^{3}$}

Ex ante vulnerability in a poverty context is simply defined as the probability that a currently non-poor household will fall below the poverty-line, or a currently poor household will remain in poverty in the near future. Formally, for per capita consumption expenditure as an indicator of households' living standard, the vulnerability of a household $i$ at time $t$ is defined as the probability that the household will fall below the poverty line, $z$,

$$
V_{i t}=\operatorname{Pr}\left(c_{i, t+1} \leq z\right)
$$

where $V_{i t}$ is vulnerability of household $i$ at time $t$ and $c_{i t+1}$ denotes $i$ 's per capita consumption expenditure at $t+1$ respectively and $z$ represents poverty threshold. Considering that a household's consumption, in general, depends on a variety of household characteristics, idiosyncratic and aggregate shocks, household i's consumption can be expressed as follows:

$$
c_{i t}=c\left(X_{i}, \beta_{t}, \alpha_{i}, \varepsilon_{i t}\right)
$$

\footnotetext{
${ }^{3}$ This section largely draws upon Chaudhuri et al. (2002)
} 
where $X_{i}$ represents the bundle of observable household characteristics, $\beta_{t}$ is a vector of parameters describing the returns to household characteristics, which reflects the state of the economy at time $t$. The terms $\alpha_{i}$ and $\varepsilon_{i t}$ capture, respectively, an unobserved time-invariant household level effect, and an error term that measures any idiosyncratic factors that contribute to differential welfare outcomes for households who are otherwise equivalent. Although $i$ 's future consumption $c_{i t+1}$ cannot be observed in time $t$, estimating the consumption equation based on (2) enables us to measure household i's vulnerability as:

$$
V_{i t}=\operatorname{Pr}\left(c_{i, t+1}=c\left(X_{i}, \beta_{t+1}, \alpha_{i}, \varepsilon_{i, t+1}\right) \leq z \mid X_{i}, \beta_{i}, \alpha_{i}, \varepsilon_{i t}\right)
$$

Thus, the household's vulnerability can be derived from the stochastic properties of the intertemporal consumption stream.

As explained earlier, our data sets are two rounds of cross-sectional with relatively large sample of households, rather than lengthy panel data. Therefore we use the following measure of VEP.

With cross-sectional data, a household consumption function is assumed as follows:

$$
\ln c_{i}=X_{i} \beta+\varepsilon_{i}
$$

where $\varepsilon_{i} \sim\left(0, X_{i} \vartheta\right)$

Assuming that the structure of the economy is relatively stable over time, future consumption stems solely from the uncertainty about the idiosyncratic shocks and unobservable characteristics, captured by $\varepsilon_{i}$, which contribute to different per capita consumption levels. It is also assumed that the variance of the disturbance is given as:

$$
\sigma_{\varepsilon, i}^{2}=X_{i} \vartheta
$$


Estimates for $\beta$ and $\vartheta$ can be found using a three-step feasible generalized least squares

(FGLS) procedure. ${ }^{4}$ Using $\hat{\beta}$ and $\hat{\vartheta}$, we can estimate the expected log consumption and the variance of log consumption for each household as follows:

$$
\begin{aligned}
& \hat{E}\left[\ln c_{i} \mid X_{i}\right]=X_{i} \hat{\beta} \\
& \hat{V}\left[\ln c_{i} \mid X_{i}\right]=X_{i} \hat{\vartheta}
\end{aligned}
$$

By assuming $\ln c_{i}$ is normally distributed and using the estimates above, the probability of falling into (for the currently non-poor), or remaining (for the currently poor), poverty in the future is given by the expression:

$$
\hat{V}_{i}=\hat{\operatorname{Pr}}\left(\ln c_{i}<\ln z \mid X_{i}\right)=\Phi\left(\frac{\ln z-X_{i} \hat{\beta}}{\sqrt{X_{i} \hat{\vartheta}}}\right)
$$

(9) reflects the presumption that high volatility of consumption reduces vulnerability for those with expected consumption below poverty line whereas it increases vulnerability for those whose expected consumption is above poverty line. Hence, if we reasonably assume that the poor are risk-averse, they might have little chance to escape from poverty.

\section{(b) Determinants of poverty}

Our method to assess the determinants of poverty is based upon estimating households' probability of being poor. Therefore, a probit model is used to estimate whether a household's monthly per capita consumption expenditure was below the poverty line, conditioned on a vector of household and village characteristics $\left(\mathrm{X}_{\mathrm{i}}\right)$.

$$
\operatorname{Pr}\left(P_{i}=1\right)=\Phi\left(X_{i} \psi^{\prime}\right)
$$

\footnotetext{
${ }^{4}$ See Chaudhuri et al. (2002) and Chaudhuri (2003) for technical details.
} 
where $P_{i}=1$ if $\ln \mathrm{c}_{\mathrm{i}}<\ln \mathrm{z}$ and $P_{i}=0$ otherwise. When 2006 data is used, we can address the association between households' vulnerability in 1999 and the probability of being poor in 2006 by adding VEP in 1999 as one of the covariates. ${ }^{5}$

\section{(c) Role of vulnerability on poverty shift between 1999 and 2006}

The estimation in Section 3.2 (i.e. the role of vulnerability on poverty) is further extended by using a multinomial logit model to analyse poverty transition over the period 1999 - 2006. The key hypotheses tested are (i) whether the vulnerable poor in 1999 were more likely to stay in poverty in 2006 (i.e. whether vulnerability traps households into poverty) and (ii) whether vulnerability was likely to increase the likelihood that the non-poor in 1999 slip into poverty in 2006.

We consider the following 4 unordered categories of poverty transition.

$P_{1}=$ those who were poor in both 1999 and 2006;

$P_{2}=$ those who were poor in 1999, but non-poor in 2006;

$P_{3}=$ those who were non-poor in 1999, but poor in 2006;

$P_{0}=$ those who were non-poor in both 1999 and 2006. This is the reference case. The multinomial logit model is written as

$$
\begin{aligned}
& \operatorname{Pr}\left(P_{i}=j\right)=\frac{e^{\left(X_{i} \lambda_{j}+\tau_{k} V E P_{i}\right)}}{1+\sum_{k=1}^{3} e^{\left(X_{i} \lambda_{k}+\tau_{k} V E P_{i}\right)}}, \quad j=1,2,3 \\
& \operatorname{Pr}\left(P_{i}=0\right)=\frac{1}{1+\sum_{k=1}^{3} e^{\left(X_{i} \lambda_{k}+\tau_{k} V E P_{i}\right)}}, \quad j=0
\end{aligned}
$$

\footnotetext{
${ }^{5}$ Also see Imai, Gaiha and Kang (2011).
} 


\section{(d) Household characteristics and vulnerability distribution: Quantile regression}

Vulnerability is similar to but distinct from poverty. We now outline how one can assess how a household's characteristics, such age of household head, the share of female members, the dependency burden and educational status of household members etc. and village characteristics are associated with poverty (ex post) and vulnerability (ex ante) as expected poverty. Hence, it offers differences, if any, in determining poverty and vulnerability, i.e. it provides key insights which might enable policymakers to construct better anti-poverty strategies.

The shortcoming of estimation to investigate the determinant of vulnerability, using Ordinary Least Squares (OLS) is that it cannot capture the different association of factors on the households' vulnerability which might vary depending on the position of the household in the overall distribution of estimated VEP. Figure 1 shows that the distribution of household vulnerability in both 1999 and 2006 were highly left-skewed. Hence, we use quantile regression techniques proposed by Koenker and Basset (1978).

$$
V \hat{E} P_{i}=X_{i} \mu_{\tau}+\varepsilon_{i i} \quad \text { with } Q_{\tau}(V \hat{E} P \mid X)=X \mu_{\tau}
$$

For any $0<\tau<1$, the coefficient $\mu_{\tau}$ of the $\tau$ the regression quantile is estimated as a solution the problem:

$$
\min _{\mu_{\tau}}\left\{\sum_{y_{i} \geq x_{i} \mu_{\tau}} \tau\left|y_{i}-x_{i} \mu_{\tau}\right|+\sum_{y_{i}<x_{i} \mu_{\tau}}(1-\tau)\left|y_{i}-x_{i} \mu_{\tau}\right|\right\} .
$$

In contrast to OLS where the parameters are estimated at the conditional sample mean of the dependent variable, the quantile regression hence enables us to determine whether a household's location in the estimated vulnerability distribution differentially affects the relationship between VEP and household characteristics. We estimate the model to the $10^{\text {th }}$, $25^{\text {th }}, 50^{\text {th }}$ (median), $75^{\text {th }}$ and $90^{\text {th }}$ percentiles. 
The quantile regression approach has several advantages. Since it is estimated by minimizing the sum of (weighted) absolute values of the residuals as shown in (14), it is robust to the existence of outliers or asymmetric error as well as the presence of heteroskedasticity (Deaton, 1997; Koenker and Hallock, 2001). Furthermore, because using the entire sample to estimate each quantile, it avoids sample selection bias problem arising from OLS approach dividing the vulnerability distribution into several subsets (Hammarstedt and Shukur, 2007).

\section{(Figure 1 here)}

\section{Results}

\section{(a) Measuring vulnerability}

Table 1 show the regression results for equations (7) and (8) whereby the log of per capita consumption for each year and variance of the disturbance term are estimated ${ }^{6}$ by household characteristics and other determinants. We will discuss a selection of the results.

\section{(Table 1 here)}

As shown in Table 1, a household with an older head tended to have lower ex ante per capita consumption as suggested by the negative and significant coefficient on age of household head, in 1999 while this coefficient is insignificant in 2006. As we expect, the higher share of members with secondary or higher education, the higher expected consumption. The coefficient estimates are strongly significant in both years. In 1999 and 2006, the coefficients of the share of female members are negative and significant and of its square - positive highly significant - confirm that, having more female members tended to substantially decrease per capita consumption, but the relationship was nonlinear. The coefficients of dependency

\footnotetext{
${ }^{6}$ Details of definitions of variables are laid out in Appendix Table 2.
} 
burden are also negative and statistically significant, implying that a household with more younger or older members would have lower consumption per capita. Having more land would increase per capita consumption but marginal change get smaller as confirmed by the negative and significant coefficient of its square. However, we cannot find any evidence of such nonlinear relationship for land in 2006. Higher share of irrigated land tended to increase household consumption in both years. Higher share of household members who participate in Gram Sabha meeting or show identity based voting pattern increase household expected consumption (their coefficients are strongly significant).

Thus, local governance issues such as attending Gram Sabha meetings and identity based voting (not just participation in voting) have strong positive influences on expected consumption in rural India. Thus, these form part of a strategy of reducing vulnerability.

At the village level, we also find that the change in gender of a pradhan as a proxy of regime change has a positive impact for household expected consumption in both periods but is significant only in 2006. As anticipated, having accesses to bus station, public school and public health services are important determinants of a household expected consumption.

Estimates of consumption and variance of disturbance term from Table 1 allow us to calculate each household's vulnerability using equation (9). As the result is sensitive to the choice of poverty line which is predetermined and arbitrary threshold, we applied $100 \%$, $120 \%$ and $80 \%$ of the poverty line of each year. Based on $100 \%$ poverty line, we obtain mean vulnerability of $28.3 \%$ in 1999 and $16.5 \%$ in 2006 for rural Indian households, i.e. a rural Indian household, on average, had $28.3 \%$ probability of falling into poverty in 1999 but this declined to $16.5 \%$ in 2006. 


\section{(b) Determinant of poverty and vulnerability}

Table 2 presents results on determinants of household ex post poverty. We find, upon replacing the coefficients of the probit model by the respective marginal effects, that ex ante vulnerability in 1999 translated into ex post poverty in 2006, i.e. 1\% increase in the ex ante probability of falling into poverty would increase ex post probability of poverty by $0.32 \%$ (based on $100 \%$ poverty line). Regardless of the poverty line used in the estimations, the coefficients of vulnerability are strongly significant in all the cases. A household headed by a female has relatively lower probability of poverty in 2006 than a household headed by a male. The coefficients of household age are positive (i.e. increase probability of poverty) and significant in 1999 but not in 2006. Higher share of more educated members, larger size of land and more irrigated land tend to reduce household probability of poverty while both more female members, and younger or older members would increase the probability of poverty. Whether women in a household inherit land was insignificant in 1999 but turned out to have a significant impact on reducing a household's probability of poverty in 2006. As confirmed from Table 1, the participation in the process of governance would, in general, have positive and significant impact on a household's living standard (i.e. it reduces the probability of poverty).

\section{(Table 2 here)}

\section{(d) Role of vulnerability in poverty shift between 1999 and 2006}

Table 3 presents a poverty transition matrix depicting the movements in and out of poverty for rural Indian households between 1999 and 2006. The headcount ratio declined from $29.9 \%$ to $22.8 \%$. Among those who were poor in 1999 about two thirds moved out of poverty by 2006. In contrast, approximately $15 \%$ of the non-poor in 1999 had fallen into poverty by 
2006. Although the proportion that moved into poverty in 2006 might not be large, implying that vulnerability may not be an urgent challenge in rural India, larger share of transient poverty (32\% both moved in/out of poverty) relative to chronic poverty might be a cause for concern that, given fluctuating households consumption, past government and past achievement in poverty reduction may vanish if unexpected risks - both covariate and idiosyncratic - occur.

(Table 3 here)

Table 4 presents results from the Multinomial logit estimation investigating the impact of vulnerability on poverty transition during the sample period. Our main interests are (i) the coefficient of the vulnerability in the third column $\left(\mathrm{P}_{3}\right)$ of each of case $\mathrm{A}, \mathrm{B}$ and $\mathrm{C}$, and (ii) difference between the second and the first columns $\left(\mathrm{P}_{2}-\mathrm{P}_{1}\right)$. The log odds of former to the base group (the chronically non poor) represents relative probability of poverty for those who were not poor in 1999 but poor in 2006 to the non-poor over 1999-2006 whereas the latter gives relative probability of moving out of poverty to the probability of staying in poverty. Therefore, the positive sign in the third columns indicates higher probability of falling into poverty while the negative sign of the difference $\left(\mathrm{P}_{2}-\mathrm{P}_{1}\right)$ implies less likelihood of moving out of poverty.

\section{(Table 4 here)}

The coefficient of vulnerability in the third column, i.e., differences between the coefficients in the third column and the base group range from 1.93 to 4.81 , and are strongly significant, implying that a rise in vulnerability tend to increase relative probability of slipping into 
poverty considerably. Besides, the coefficient difference between the second and first columns, which is negative, in each case suggests that relative probability of escaping poverty decreases as vulnerability increases. ${ }^{7}$ Therefore, it might be argued that reducing vulnerability does not only prevent a household from falling into poverty (i.e. protective effect), but also promotes a household's escape from poverty (i.e. promotional effect).

We now selectively present some other results. An increase in land holding, and larger share of the irrigated land expectedly tend to reduce relative probability of falling into poverty and increase the relative probability of moving out poverty. The coefficient differences are all significant at $1 \%$ or $5 \%$. In contrast, both higher female share and dependency burden increase the probability of falling into poverty and reduce the likelihood of escaping poverty. The higher the share of household members who participated in Gram Sabha meeting the lower is the probability of falling into poverty, but this significant at $10 \%$ in all cases. We cannot find statistically significant 'protective' effect from identity based voting pattern. However, it is interesting that higher share of household members with identity based voting pattern would promote households moving out poverty. Village characteristics such as access to bus station and access to public health services are likely to reduce the probability of falling into poverty.

\section{(d) Household characteristics and vulnerability distribution: Quantile regression}

We now selectively discuss results obtained from simultaneous quantile regression. Note that the $10^{\text {th }}$ percentile group represents the least vulnerable, that is, the most well-off group as the dependent variable in the model is household vulnerability. Figure 2 shows the varying association of some selected households characteristics with vulnerability over household

\footnotetext{
${ }^{7}$ We carried out statistical test and confirmed that the differences in the coefficients are statistically significant at $1 \%$. Also the Hausman tests for the IIA assumption with respect to our multinomial logit model support the hypothesis that omitting one of the categories will not change the coefficient estimates systematically. These results will be furnished upon request.
} 
locations in the vulnerability distribution and distributional changes between the two periods. Full results are given in Appendix Table 1 where the dependent variable is estimated VEP.

\section{(Figure 2 here)}

The vulnerability reducing effect of education, proxied by the share of household members with secondary or higher education, is found to be largest at $10^{\text {th }}$ percentile group in 1999 and this effect was declining across the vulnerability distribution. However, the role of education for this group sharply weakened in 2006. Not only was this group the best-off group in the sample, who might have had the highest share of educated members, but also they were likely to be the first to realise the benefits of economic growth. Hence, the marginal effect of the share of educated member declined in 2006. In contrast, the role of education on reducing vulnerability marginally increased across vulnerability deciles in 2006. In both 1999 and 2006, we observe that the higher is the share of female members, the higher is the vulnerability. However, its association with households vulnerability became more significant in the more vulnerable groups in 2006 (e.g. lower 50\%) while it had more significant influence on less vulnerable group (e.g. upper 50\%) in 1999. This might imply that females in the better off households had benefitted more from economic growth during 1999-2006 relative to those in the worse-off households. It is interesting that the fact of women inheriting land tended to increase vulnerability in less vulnerable groups (upper 50\% population) while it reduced vulnerability in more vulnerable groups (lower 50\% population) in 1999. However, it turned out to reduce household vulnerability overall and its marginal effects are increasing across the vulnerability distribution. The vulnerability mitigating impacts of household participation in local governance are observed across all quantiles in 1999 and 2006. In particular, the increasing marginal effect of participation in Gram Sabha meeting might suggest that by participating in local political processes the more vulnerable 
groups would have a greater benefit in lowering the probability of future poverty than less vulnerable groups. Finally, turning to village characteristics, access to bus station tended to reduce household vulnerability and was found to be more significant in more vulnerable group as shown from Figure 2. Both accesses to school and public health services are negatively associated with household vulnerability as we would expect.

\section{Policy implications and conclusion}

Using a unique panel data for rural India for the periods 1999 and 2006 this paper has modelled vulnerability to poverty. We quantify household vulnerability in rural India in 1999 and 2006, investigate the determinants of ex post poverty as well as ex ante vulnerability, assess the role of ex ante vulnerability on poverty shift during the sample periods (i.e. movement into/out of poverty) and finally, examine how the effects of the determinants of vulnerability vary at different points across the vulnerability distribution.

This paper concludes that over time economic growth has reduced the incidence of poverty. Although chronic poverty is relatively small the high incidence of transient poverty underscores the importance of covariate and idiosyncratic shocks. Household vulnerability across the distribution of such vulnerability is also investigated. A number of factors affect such vulnerability across this distribution. Apart from expected factors such as age and gender of household head, education and land owned some governance factors such as attendance of Gram Sabha meetings and identity based voting influence vulnerability. Thus the paper isolates a number of characteristics of households and policy variables which can be targeted to reduce the incidence of vulnerability in rural India. 


\section{$\underline{\text { References }}$}

Barrientos, A. (2007) ‘Does Vulnerability Create Poverty Traps?’, CRPC Working Paper 76, University of Manchester.

Chaudhuri, S. (2003) 'Assessing Vulnerability to Poverty: Concepts, Empirical Methods and Illustrative Examples’, mimeo, Columbia University.

Chaudhuri, S., Jalan J. and Suryahadi, A. (2002) 'Assessing Household Vulnerability to Poverty: A Methodology and Estimates for Indonesia’, Discussion Paper, No. 0102-52, Columbia University.

Deaton, A. (1997) The Analysis of Household Surveys: A Microeconometric Approach to Development Policy, Baltimore and London: The Johns Hopkins University Press.

Dercon, S. (2005) (ed.) Insurance Against Poverty, New York: Oxford University Press.

Gaiha, R. and A. Deolalikar (1993) 'Persistent, Expected and Innate Poverty: Estimates for semi-arid Rural India’, Cambridge Journal of Economics, 17(4), pp. 409-21.

Hammarstedt, M. and Shukur, G. (2007) 'Immigrants’ Relative Earnings in Sweden - A Quantile Regression Approach’, International Journal of Manpower, 28(6), pp. 456-73. Imai, K., Gaiha, R. and Kang, W. (2011) 'Vulnerability and Poverty Dynamics in Vietnam', Applied Economics, 43(25), pp. 3603-18.

Jalan, J. and M.Ravallion (2001) 'Behavioral Responses to Risk in Rural China', Journal of Development Economics, 66(1), pp. 23-49.

Koenker, R. and Bassett, G. (1978) 'Regression Quantiles’, Econometrica, 46(1), pp. 33-50.

Koenker, R. and Hallock, K. (2001) 'Quantile Regression’, Journal of Economic Perspectives, 15(4), pp. 143-56.

McCulloch, N. and M. Calandrino (2003) 'Vulnerability and Chronic Poverty in Rural Sichuan', World Development, 31(3), pp. 611-28.

Ravallion, M. (1988) ‘Expected Poverty under Risk-Induced Welfare Variability’, The Economic Journal, 98(393), pp. 1171-82.

Suryahadi, Asep, Sudarno Sumarto, Yusuf Suharso, and Lant Pritchett (2000), The Evolution of Poverty during the Crisis in Indonesia, 1996 to 1999 (Using FullSusenas Sample), SMERU Working Paper, March, Social Monitoring \& Early Response Unit, Jakarta. Townsend, R. (1994) 'Risk and Insurance in Rural India’, Econometrica, 62(3), pp. 539-91. Udry, C. (1990) 'Credit Markets in Northern Nigeria: Credit as Insurance in a Rural Economy', World Bank Economic Review, 4(3), pp.251-69. 
Table 1. Estimates for the measure of VEP

\begin{tabular}{|c|c|c|c|c|}
\hline & \multicolumn{2}{|c|}{1999} & \multicolumn{2}{|r|}{2006} \\
\hline & $\log ($ Cons $)$ & Variance & $\log ($ Cons $)$ & Variance \\
\hline fhead & $\begin{array}{l}0.037 \\
(1.42)\end{array}$ & $\begin{array}{c}0.367 \\
(2.32)^{* *}\end{array}$ & $\begin{array}{c}0.062 \\
(2.54)^{* *}\end{array}$ & $\begin{array}{l}0.015 \\
(0.11)\end{array}$ \\
\hline Age_head & $\begin{array}{c}-0.012 \\
(4.87)^{* * *}\end{array}$ & $\begin{array}{l}-0.013 \\
(0.81)\end{array}$ & $\begin{array}{l}-0.002 \\
(0.55)\end{array}$ & $\begin{array}{l}-0.022 \\
(1.29)\end{array}$ \\
\hline (Age_head)2 & $\begin{array}{c}0 \\
(4.29)^{* * *}\end{array}$ & $\begin{array}{c}0 \\
(0.76)\end{array}$ & $\begin{array}{c}0 \\
(1.46)\end{array}$ & $\begin{array}{c}0 \\
(1.54)\end{array}$ \\
\hline seconedushare & $\begin{array}{c}0.465 \\
(17.07)^{* * *}\end{array}$ & $\begin{array}{l}0.134 \\
(0.71)\end{array}$ & $\begin{array}{c}0.089 \\
(3.19)^{* * *}\end{array}$ & $\begin{array}{c}0.284 \\
(1.86)^{*}\end{array}$ \\
\hline femaleshare & $\begin{array}{c}-0.951 \\
(5.92)^{* * *}\end{array}$ & $\begin{array}{l}-1.601 \\
(1.63)\end{array}$ & $\begin{array}{c}-0.603 \\
(3.42)^{* * *}\end{array}$ & $\begin{array}{l}-0.274 \\
(0.30)\end{array}$ \\
\hline femaleshare2 & $\begin{array}{c}0.871 \\
(5.27)^{* * *}\end{array}$ & $\begin{array}{c}2.063 \\
(2.12)^{* *}\end{array}$ & $\begin{array}{c}0.539 \\
(3.21)^{* * *}\end{array}$ & $\begin{array}{l}0.341 \\
(0.40)\end{array}$ \\
\hline dependency & $\begin{array}{c}-0.118 \\
(3.73)^{* * *}\end{array}$ & $\begin{array}{c}0.32 \\
(1.46)\end{array}$ & $\begin{array}{c}-0.144 \\
(3.70)^{* * *}\end{array}$ & $\begin{array}{c}0.507 \\
(2.57)^{* *}\end{array}$ \\
\hline Tot_land & $\begin{array}{c}0.017 \\
(12.34)^{* * *}\end{array}$ & $\begin{array}{c}0.02 \\
(2.79)^{* * *}\end{array}$ & $\begin{array}{c}0.01 \\
(5.00)^{* * *}\end{array}$ & $\begin{array}{c}0 \\
(0.01)\end{array}$ \\
\hline (Tot_land)2 & $\begin{array}{c}0 \\
(3.47)^{* * *}\end{array}$ & $\begin{array}{c}0 \\
(0.70)\end{array}$ & $\begin{array}{c}0 \\
(0.14)\end{array}$ & $\begin{array}{c}0 \\
(0.62)\end{array}$ \\
\hline land_irrshare & $\begin{array}{c}0.124 \\
(10.76)^{* * *}\end{array}$ & $\begin{array}{l}-0.07 \\
(0.86)\end{array}$ & $\begin{array}{c}0.117 \\
(7.89)^{* * *}\end{array}$ & $\begin{array}{l}-0.103 \\
(1.29)\end{array}$ \\
\hline hhsplit & $\begin{array}{c}0.037 \\
(3.70)^{* * *}\end{array}$ & $\begin{array}{l}0.068 \\
(0.97)\end{array}$ & $\begin{array}{l}0.019 \\
(1.31)\end{array}$ & $\begin{array}{c}-0.219 \\
(2.80)^{* * *}\end{array}$ \\
\hline inherit & $\begin{array}{l}0.019 \\
(0.87)\end{array}$ & $\begin{array}{l}0.054 \\
(0.36)\end{array}$ & $\begin{array}{c}0.037 \\
(2.56)^{* *}\end{array}$ & $\begin{array}{l}-0.077 \\
(0.96)\end{array}$ \\
\hline Prop_GS & $\begin{array}{c}0.099 \\
(2.62)^{* * *}\end{array}$ & $\begin{array}{l}-0.202 \\
(0.70)\end{array}$ & $\begin{array}{c}0.127 \\
(2.62)^{* * *}\end{array}$ & $\begin{array}{l}0.345 \\
(1.37)\end{array}$ \\
\hline Prop_IBV & $\begin{array}{c}0.146 \\
(6.50)^{* * *}\end{array}$ & $\begin{array}{c}-0.381 \\
(2.25)^{* *}\end{array}$ & $\begin{array}{c}0.167 \\
(5.97)^{* * *}\end{array}$ & $\begin{array}{l}-0.097 \\
(0.64)\end{array}$ \\
\hline $\mathrm{RC}$ & $\begin{array}{l}0.009 \\
(0.85)\end{array}$ & $\begin{array}{l}-0.088 \\
(1.16)\end{array}$ & $\begin{array}{c}0.026 \\
(1.96)^{* *}\end{array}$ & $\begin{array}{l}-0.074 \\
(1.06)\end{array}$ \\
\hline bus_d & $\begin{array}{c}0.073 \\
(6.11)^{* * *}\end{array}$ & $\begin{array}{l}-0.078 \\
(0.94)\end{array}$ & $\begin{array}{c}0.092 \\
(6.34)^{* * *}\end{array}$ & $\begin{array}{l}-0.098 \\
(1.26)\end{array}$ \\
\hline school_d & $\begin{array}{c}0.022 \\
(2.26)^{* *}\end{array}$ & $\begin{array}{l}0.091 \\
(1.34)\end{array}$ & $\begin{array}{c}0.086 \\
(2.88)^{* * *}\end{array}$ & $\begin{array}{l}0.036 \\
(0.23)\end{array}$ \\
\hline hospital_d & $\begin{array}{c}0.063 \\
(4.22)^{* * *}\end{array}$ & $\begin{array}{c}-0.12 \\
(1.12)\end{array}$ & $\begin{array}{c}0.032 \\
(1.96)^{* *}\end{array}$ & $\begin{array}{l}-0.092 \\
(1.05)\end{array}$ \\
\hline financial_d & $\begin{array}{l}-0.003 \\
(0.27)\end{array}$ & $\begin{array}{c}0.217 \\
(2.87)^{* * *}\end{array}$ & $\begin{array}{l}0.013 \\
(0.87)\end{array}$ & $\begin{array}{l}0.069 \\
(0.85)\end{array}$ \\
\hline Pubtab_d & $\begin{array}{l}0.013 \\
(1.04)\end{array}$ & $\begin{array}{l}0.012 \\
(0.14)\end{array}$ & $\begin{array}{l}0.022 \\
(1.21)\end{array}$ & $\begin{array}{l}-0.008 \\
(0.08)\end{array}$ \\
\hline Constant & $\begin{array}{c}8.88 \\
(114.73)\end{array}$ & $\begin{array}{l}-3.402 \\
(6.37) \\
\end{array}$ & $\begin{array}{c}8.125 \\
(70.26) \\
\end{array}$ & $\begin{array}{l}-2.231 \\
(3.80) \\
\end{array}$ \\
\hline Observations & 4743 & 4743 & 4503 & 4503 \\
\hline R-squared & 0.45 & 0.02 & 0.33 & 0.03 \\
\hline Joint & $F(34,4708)$ & $F(34,4708)$ & $\mathrm{F}(36,4466)$ & $F(36,4466)$ \\
\hline Significance & $=113.56$ & $=3.39$ & $=60.31$ & $=3.95$ \\
\hline Prob > F & 0.0000 & 0.0000 & 0.0000 & 0.0000 \\
\hline
\end{tabular}

Absolute value of $\mathrm{t}$ statistics in parentheses

* significant at $10 \%$; ** significant at $5 \%$; *** significant at $1 \%$

Source: REDS 1999 and 2006 
Table 2. Determinants of Poverty

\begin{tabular}{|c|c|c|c|c|c|c|}
\hline & \multicolumn{3}{|c|}{ Whether poor in 1999: Probit (dF/dx) } & \multicolumn{3}{|c|}{ Whether poor in 2006: Probit (dF/dx) } \\
\hline & $\begin{array}{c}100 \% \text { poverty } \\
\text { line }\end{array}$ & $120 \%$ & $80 \%$ & $100 \%$ & $120 \%$ & $80 \%$ \\
\hline VEP99_100 & & & & $\begin{array}{c}0.32 \\
(9.02)^{* * *}\end{array}$ & & \\
\hline VEP99_120 & & & & & $\begin{array}{c}0.401 \\
(10.63)^{* * *}\end{array}$ & \\
\hline VEP99_80 & & & & & & $\begin{array}{c}0.181 \\
(5.42)^{* * *}\end{array}$ \\
\hline fhead & $\begin{array}{l}-0.019 \\
(0.54)\end{array}$ & $\begin{array}{l}-0.026 \\
(0.63)\end{array}$ & $\begin{array}{l}0.002 \\
(0.10)\end{array}$ & $\begin{array}{c}-0.067 \\
(2.30)^{* *}\end{array}$ & $\begin{array}{l}-0.046 \\
(1.36)\end{array}$ & $\begin{array}{c}-0.047 \\
(2.46)^{* *}\end{array}$ \\
\hline Age_head & $\begin{array}{c}0.015 \\
(3.99) * * *\end{array}$ & $\begin{array}{c}0.024 \\
(5.60)^{* * *}\end{array}$ & $\begin{array}{l}0.004 \\
(1.61)\end{array}$ & $\begin{array}{l}0.003 \\
(0.66)\end{array}$ & $\begin{array}{l}-0.007 \\
(1.60)\end{array}$ & $\begin{array}{l}-0.002 \\
(0.62)\end{array}$ \\
\hline (Age_head)2 & $\begin{array}{c}0 \\
(3.53)^{* * *}\end{array}$ & $\begin{array}{c}0 \\
(5.04)^{* * *}\end{array}$ & $\begin{array}{c}0 \\
(1.41)\end{array}$ & $\begin{array}{c}0 \\
(1.67)^{*}\end{array}$ & $\begin{array}{c}0 \\
(0.42)\end{array}$ & $\begin{array}{c}0 \\
(0.29)\end{array}$ \\
\hline seconedushare & $\begin{array}{c}-0.55 \\
(11.49)^{* * *}\end{array}$ & $\begin{array}{c}-0.676 \\
(12.78)^{* * *}\end{array}$ & $\begin{array}{c}-0.241 \\
(7.69)^{* * *}\end{array}$ & $\begin{array}{l}-0.015 \\
(0.45)\end{array}$ & $\begin{array}{c}-0.087 \\
(2.21)^{* *}\end{array}$ & $\begin{array}{l}0.001 \\
(0.04)\end{array}$ \\
\hline femaleshare & $\begin{array}{c}1.206 \\
(5.27)^{* * *}\end{array}$ & $\begin{array}{c}1.515 \\
(5.57)^{* * *}\end{array}$ & $\begin{array}{c}0.424 \\
(3.04)^{* * *}\end{array}$ & $\begin{array}{c}0.37 \\
(\mathbf{1 . 6 8 )}\end{array}$ & $\begin{array}{c}0.637 \\
(2.59)^{* * *}\end{array}$ & $\begin{array}{l}0.101 \\
(0.65)\end{array}$ \\
\hline femaleshare2 & $\begin{array}{c}-1.044 \\
(4.62)^{* * *}\end{array}$ & $\begin{array}{c}-1.346 \\
(4.97)^{* * *}\end{array}$ & $\begin{array}{c}-0.373 \\
(2.70)^{* * *}\end{array}$ & $\begin{array}{l}-0.302 \\
(1.46)\end{array}$ & $\begin{array}{c}-0.583 \\
(2.50)^{* *}\end{array}$ & $\begin{array}{l}-0.055 \\
(0.38)\end{array}$ \\
\hline dependency & $\begin{array}{c}0.236 \\
(4.87)^{* * *}\end{array}$ & $\begin{array}{c}0.254 \\
(4.36)^{* * *}\end{array}$ & $\begin{array}{c}0.073 \\
(2.62)^{* * *}\end{array}$ & $\begin{array}{c}0.227 \\
(5.14)^{* * *}\end{array}$ & $\begin{array}{c}0.124 \\
(2.39)^{* *}\end{array}$ & $\begin{array}{c}0.104 \\
(3.62)^{* * *}\end{array}$ \\
\hline Tot_land & $\begin{array}{c}-0.016 \\
(7.14)^{* * *}\end{array}$ & $\begin{array}{c}-0.024 \\
(10.06)^{* * *}\end{array}$ & $\begin{array}{c}-0.006 \\
(4.30)^{* * *}\end{array}$ & $\begin{array}{c}-\mathbf{0 . 0 1 6} \\
(3.55)^{* * *}\end{array}$ & $\begin{array}{c}-0.015 \\
(3.57)^{* * *}\end{array}$ & $\begin{array}{c}-0.012 \\
(4.30)^{* * *}\end{array}$ \\
\hline (Tot_land)2 & $\begin{array}{c}0 \\
(5.10)^{* * *}\end{array}$ & $\begin{array}{c}0 \\
(6.87)^{* * *}\end{array}$ & $\begin{array}{c}0 \\
(3.15)^{* * *}\end{array}$ & $\begin{array}{c}0 \\
(3.09)^{* * *}\end{array}$ & $\begin{array}{c}0 \\
(2.82)^{* * *}\end{array}$ & $\begin{array}{c}0 \\
(3.37)^{* * *}\end{array}$ \\
\hline land_irrshare & $\begin{array}{c}-0.168 \\
(9.02)^{* * *}\end{array}$ & $\begin{array}{c}-0.169 \\
(7.86)^{* * *}\end{array}$ & $\begin{array}{c}-0.097 \\
(8.34)^{* * *}\end{array}$ & $\begin{array}{c}-0.072 \\
(3.81)^{* * *}\end{array}$ & $\begin{array}{c}-0.074 \\
(3.50)^{* * *}\end{array}$ & $\begin{array}{c}-0.049 \\
(3.76)^{* * *}\end{array}$ \\
\hline hhsplit & $\begin{array}{c}-0.034 \\
(2.21)^{* *}\end{array}$ & $\begin{array}{c}-0.065 \\
(3.53)^{* * *}\end{array}$ & $\begin{array}{l}-0.011 \\
(1.16)\end{array}$ & $\begin{array}{l}-0.023 \\
(1.36)\end{array}$ & $\begin{array}{l}-0.026 \\
(1.29)\end{array}$ & $\begin{array}{c}-0.046 \\
(4.03)^{* * *}\end{array}$ \\
\hline inherit & $\begin{array}{l}0.027 \\
(0.80)\end{array}$ & $\begin{array}{l}-0.05 \\
(1.30)\end{array}$ & $\begin{array}{l}-0.004 \\
(0.21)\end{array}$ & $\begin{array}{c}-0.032 \\
(1.77)^{*}\end{array}$ & $\begin{array}{c}-0.057 \\
(2.77)^{* * *}\end{array}$ & $\begin{array}{c}-0.021 \\
(1.82)^{*}\end{array}$ \\
\hline Prop_GS & $\begin{array}{l}-0.108 \\
(1.74)^{*}\end{array}$ & $\begin{array}{l}-0.08 \\
(1.00)\end{array}$ & $\begin{array}{c}-0.095 \\
(2.77)^{* * *}\end{array}$ & $\begin{array}{l}-0.091 \\
(1.58)\end{array}$ & $\begin{array}{c}-0.136 \\
(2.04)^{* *}\end{array}$ & $\begin{array}{l}-0.081 \\
(1.94)^{*}\end{array}$ \\
\hline Prop_IBV & $\begin{array}{c}-0.174 \\
(4.74)^{* * *}\end{array}$ & $\begin{array}{c}-0.198 \\
(4.43)^{* * *}\end{array}$ & $\begin{array}{c}-0.059 \\
(2.79)^{* * *}\end{array}$ & $\begin{array}{c}-0.08 \\
(2.29)^{* *}\end{array}$ & $\begin{array}{l}-0.046 \\
(1.15)\end{array}$ & $\begin{array}{c}-0.064 \\
(2.64)^{* * *}\end{array}$ \\
\hline $\mathrm{RC}$ & $\begin{array}{c}-0.031 \\
(1.92)^{*}\end{array}$ & $\begin{array}{c}-0.038 \\
(1.94)^{*}\end{array}$ & $\begin{array}{l}-0.013 \\
(1.37)\end{array}$ & $\begin{array}{l}-0.023 \\
(1.44)\end{array}$ & $\begin{array}{l}-0.015 \\
(0.81)\end{array}$ & $\begin{array}{c}-0.019 \\
(1.83)^{*}\end{array}$ \\
\hline bus_d & $\begin{array}{c}-0.093 \\
(5.08)^{* * *}\end{array}$ & $\begin{array}{c}-0.114 \\
(5.23)^{* * *}\end{array}$ & $\begin{array}{c}-0.029 \\
(2.67)^{* * *}\end{array}$ & $\begin{array}{c}-0.061 \\
(3.37)^{* * *}\end{array}$ & $\begin{array}{c}-0.051 \\
(2.48)^{* *}\end{array}$ & $\begin{array}{c}-0.06 \\
(5.13)^{* * *}\end{array}$ \\
\hline school_d & $\begin{array}{c}-0.061 \\
(4.08)^{* * *}\end{array}$ & $\begin{array}{l}-0.023 \\
(1.34)\end{array}$ & $\begin{array}{c}-0.019 \\
(2.07)^{* *}\end{array}$ & $\begin{array}{l}-0.039 \\
(1.00)\end{array}$ & $\begin{array}{l}-0.013 \\
(0.33)\end{array}$ & $\begin{array}{c}-0.059 \\
(1.97)^{* *}\end{array}$ \\
\hline hospital_d & $\begin{array}{c}-0.079 \\
(3.30)^{* * *}\end{array}$ & $\begin{array}{c}-0.073 \\
(2.59)^{* * *}\end{array}$ & $\begin{array}{c}-0.057 \\
(3.74)^{* * *}\end{array}$ & $\begin{array}{c}-0.052 \\
(2.43)^{* *}\end{array}$ & $\begin{array}{l}-0.037 \\
(1.60)\end{array}$ & $\begin{array}{l}-0.019 \\
(1.27)\end{array}$ \\
\hline financial_d & $\begin{array}{c}0.02 \\
(1.23)\end{array}$ & $\begin{array}{l}0.022 \\
(1.10)\end{array}$ & $\begin{array}{l}-0.003 \\
(0.27)\end{array}$ & $\begin{array}{l}0.004 \\
(0.20)\end{array}$ & $\begin{array}{l}-0.012 \\
(0.57)\end{array}$ & $\begin{array}{c}0.029 \\
(2.25)^{* *}\end{array}$ \\
\hline Pubtab_d & $\begin{array}{l}-0.001 \\
(0.05)\end{array}$ & $\begin{array}{l}0.016 \\
(0.70)\end{array}$ & $\begin{array}{l}-0.016 \\
(1.40)\end{array}$ & $\begin{array}{l}0.002 \\
(0.10)\end{array}$ & $\begin{array}{c}-0.082 \\
(3.21)^{* * *}\end{array}$ & $\begin{array}{l}0.007 \\
(0.43)\end{array}$ \\
\hline Observations & 4743 & 4743 & 4443 & 3618 & 3782 & 3618 \\
\hline $\begin{array}{l}\text { Pseudo } \mathrm{R}^{2} \\
\text { Joint } \\
\text { significance }\end{array}$ & $\begin{array}{c}0.3 \\
\text { Wald chi2(34) } \\
=1213.64\end{array}$ & $\begin{array}{c}0.3 \\
\text { Wald chi2(34) } \\
=1335.86\end{array}$ & $\begin{array}{c}0.26 \\
\text { Wald chi2(34) } \\
=790.23\end{array}$ & $\begin{array}{c}0.16 \\
\text { Wald chi2(36) } \\
=556.00\end{array}$ & $\begin{array}{c}0.15 \\
\text { Wald chi2(37) } \\
=677.56\end{array}$ & $\begin{array}{c}\quad 0.18 \\
\text { Wald chi2(36) } \\
=458.43\end{array}$ \\
\hline Prob $>$ chi2 & 0.0000 & 0.0000 & 0.0000 & 0.0000 & 0.0000 & 0.0000 \\
\hline
\end{tabular}

Robust z statistics in parentheses

* significant at $10 \%$; ** significant at $5 \%$; *** significant at $1 \%$

Source: REDS 1999 and 2006 
Table 3. Poverty transition matrix between 1999 and 2006

\begin{tabular}{cccc}
\hline & \multicolumn{2}{c}{ Status in 2006} & Total \\
\hline Status in 1999 & Poor & Non-poor & 1,747 \\
Poor & 616 & 1,131 & $(29.9)$ \\
& $(10.6)$ & $(19.4)$ & 4,094 \\
Non-poor & 713 & 3,381 & $(70.1)$ \\
& $(12.2)$ & $(57.9)$ & 5,841 \\
Total & 1,329 & 4,512 & $(100)$ \\
\hline
\end{tabular}

Based on the panel households in the sample data

Head count ratio in parentheses

Source: REDS 1999 and 2006 
Table 4. Poverty transition during 1999 - 2006 (Multinomial Logit)

\begin{tabular}{|c|c|c|c|c|c|c|c|c|c|}
\hline & $\begin{array}{l}\text { Poor -> } \\
\text { Poor }\end{array}$ & $\begin{array}{l}\text { Poor -> } \\
\text { Not poor }\end{array}$ & $\begin{array}{l}\text { Not poor } \\
->\text { Poor }\end{array}$ & $\begin{array}{l}\text { Poor -> } \\
\text { Poor }\end{array}$ & $\begin{array}{c}\text { Poor -> } \\
\text { Not poor }\end{array}$ & $\begin{array}{l}\text { Not poor } \\
->\text { Poor }\end{array}$ & $\begin{array}{l}\text { Poor -> } \\
\text { Poor }\end{array}$ & $\begin{array}{l}\text { Poor -> } \\
\text { Not poor }\end{array}$ & $\begin{array}{r}\text { Not poor } \\
->\text { Poor }\end{array}$ \\
\hline VEP99_100 & $\begin{array}{c}5.874 \\
(17.37)^{\star \star \star}\end{array}$ & $\begin{array}{c}4.559 \\
(18.39)^{\star \star \star}\end{array}$ & $\begin{array}{c}2783 \\
(9.31)^{\star \star \star}\end{array}$ & & & & & & \\
\hline VEP99_120 & & & & $\begin{array}{c}5.812 \\
(15.73)^{\star \star \star}\end{array}$ & $\begin{array}{c}4.314 \\
(18.35)^{\star \star \star}\end{array}$ & $\begin{array}{l}1.93 \\
(7.67)^{\star \star * *}\end{array}$ & & & \\
\hline VEP99_80 & & & & & & & $\begin{array}{c}8.274 \\
(14.85)^{\star \star \star}\end{array}$ & $\begin{array}{c}6.886 \\
(14.05)^{\star \star \star}\end{array}$ & $\begin{array}{c}4.881 \\
(8.51)^{\star \star \star}\end{array}$ \\
\hline fhead & $\begin{array}{l}-0.152 \\
-0.63\end{array}$ & $\begin{array}{l}0.024 \\
-0.12\end{array}$ & $\begin{array}{l}-0.715 \\
(287)^{\star * *}\end{array}$ & $\begin{array}{l}-0.191 \\
-0.79\end{array}$ & $\begin{array}{l}0.008 \\
-0.04\end{array}$ & $\begin{array}{l}-0.716 \\
(289)^{\star * *}\end{array}$ & $\begin{array}{l}-0.104 \\
-0.44\end{array}$ & $\begin{array}{l}0.101 \\
-0.53\end{array}$ & $\begin{array}{l}-0.663 \\
(2.68)^{\star \star *}\end{array}$ \\
\hline Age_head & $\begin{array}{l}0.021 \\
-0.65\end{array}$ & $\begin{array}{c}0.054 \\
(2.04)^{\star *}\end{array}$ & $\begin{array}{c}0.056 \\
(176)^{*}\end{array}$ & $\begin{array}{l}0.023 \\
-0.7\end{array}$ & $\begin{array}{c}0.054 \\
(2.04)^{\star *}\end{array}$ & $\begin{array}{l}0.052 \\
-1.63\end{array}$ & $\begin{array}{l}0.013 \\
-0.42\end{array}$ & $\begin{array}{c}0.046 \\
(1.77)^{*}\end{array}$ & $\begin{array}{c}0.053 \\
(168)^{\star}\end{array}$ \\
\hline (Age_head)2 & $\begin{array}{l}0 \\
-1.39\end{array}$ & $\begin{array}{l}-0.001 \\
(2.18)^{\star *}\end{array}$ & $\begin{array}{l}-0.001 \\
(246)^{\star *}\end{array}$ & $\begin{array}{l}0 \\
-1.36\end{array}$ & $\begin{array}{l}-0.001 \\
(2.09)^{\star *}\end{array}$ & $\begin{array}{l}-0.001 \\
(2.29)^{* *}\end{array}$ & $\begin{array}{l}0 \\
-1.22\end{array}$ & $\begin{array}{l}0 \\
(1.93)^{*}\end{array}$ & $\begin{array}{l}-0.001 \\
(2.39)^{\star *}\end{array}$ \\
\hline seconedushare & $\begin{array}{l}-0.884 \\
(3.14)^{\star * *}\end{array}$ & $\begin{array}{l}-0.892 \\
(3.83)^{\star \star \star}\end{array}$ & $\begin{array}{l}-0.017 \\
-0.07\end{array}$ & $\begin{array}{l}-0.882 \\
(3.10)^{\star * *}\end{array}$ & $\begin{array}{l}-0.897 \\
(3.80)^{\star \star \star}\end{array}$ & $\begin{array}{l}-0.008 \\
-0.03\end{array}$ & $\begin{array}{l}-0.864 \\
(3.16)^{\star \star *}\end{array}$ & $\begin{array}{l}-0.856 \\
(3.80)^{\star \star *}\end{array}$ & $\begin{array}{l}0.002 \\
-0.01\end{array}$ \\
\hline femaleshare & $\begin{array}{c}4.387 \\
(2.34)^{\star \star}\end{array}$ & $\begin{array}{l}0.405 \\
-0.3\end{array}$ & $\begin{array}{l}0.134 \\
-0.09\end{array}$ & $\begin{array}{c}4.091 \\
(2.21)^{\star \star}\end{array}$ & $\begin{array}{r}0.35 \\
-0.26\end{array}$ & $\begin{array}{l}0.123 \\
-0.08\end{array}$ & $\begin{array}{c}4.384 \\
(2.40)^{\star *}\end{array}$ & $\begin{array}{l}0.353 \\
-0.27\end{array}$ & $\begin{array}{l}0.165 \\
-0.11\end{array}$ \\
\hline femaleshare2 & $\begin{array}{l}-4.45 \\
(2.45)^{\star *}\end{array}$ & $\begin{array}{l}-0.653 \\
-0.5\end{array}$ & $\begin{array}{l}0.437 \\
-0.3\end{array}$ & $\begin{array}{l}-4.221 \\
(2.35)^{\star *}\end{array}$ & $\begin{array}{l}-0.641 \\
-0.5\end{array}$ & $\begin{array}{l}0.43 \\
-0.3\end{array}$ & $\begin{array}{l}-4.451 \\
(2.52)^{\star *}\end{array}$ & $\begin{array}{l}-0.638 \\
-0.51\end{array}$ & $\begin{array}{l}0.387 \\
-0.27\end{array}$ \\
\hline dependency & $\begin{array}{c}1.662 \\
(4.40) * \star *\end{array}$ & $\begin{array}{c}0.694 \\
(2.32)^{\star *}\end{array}$ & $\begin{array}{c}1.509 \\
(4.48) * \star *\end{array}$ & $\begin{array}{c}1.588 \\
(4.18)^{\star \star *}\end{array}$ & $\begin{array}{l}0.652 \\
(216)^{\star *}\end{array}$ & $\begin{array}{c}1.458 \\
(4.33)^{\star * \star}\end{array}$ & $\begin{array}{c}1.588 \\
(4.29)^{* \star *}\end{array}$ & $\begin{array}{c}0.605 \\
(2.09)^{\star *}\end{array}$ & $\begin{array}{c}1.468 \\
(4.39)^{\star \star \star}\end{array}$ \\
\hline Tot_land & $\begin{array}{l}-0.165 \\
(4.21)^{\star \star \star}\end{array}$ & $\begin{array}{l}0.022 \\
-0.59\end{array}$ & $\begin{array}{l}-0.07 \\
(2.79)^{* \star \star}\end{array}$ & $\begin{array}{l}-0.163 \\
(4.10)^{\star \star \star *}\end{array}$ & $\begin{array}{r}0.03 \\
-0.78\end{array}$ & $\begin{array}{l}-0.068 \\
(2.69)^{\star \star \star *}\end{array}$ & $\begin{array}{l}-0.197 \\
(5.15)^{\star \star *}\end{array}$ & $\begin{array}{l}-0.004 \\
-0.11\end{array}$ & $\begin{array}{l}-0.086 \\
(3.40)^{\star \star \star \star}\end{array}$ \\
\hline (Tot_land)2 & $\begin{array}{c}0.001 \\
(2.14)^{* *}\end{array}$ & $\begin{array}{l}-0.003 \\
-1.4\end{array}$ & $\begin{array}{l}0 \\
-1.09\end{array}$ & $\begin{array}{c}0.001 \\
(2.21)^{\star \star}\end{array}$ & $\begin{array}{l}-0.003 \\
-1.26\end{array}$ & $\begin{array}{l}0 \\
-1.11\end{array}$ & $\begin{array}{c}0.001 \\
(2.38)^{\star \star}\end{array}$ & $\begin{array}{l}-0.004 \\
-1.46\end{array}$ & $\begin{array}{l}0 \\
-1.28\end{array}$ \\
\hline land_irrshare & $\begin{array}{l}-0.419 \\
(2.67)^{\star * *}\end{array}$ & $\begin{array}{l}-0.001 \\
-0.01\end{array}$ & $\begin{array}{l}-0.297 \\
(2.16)^{\star \star}\end{array}$ & $\begin{array}{l}-0.361 \\
(2.29)^{\star \star}\end{array}$ & $\begin{array}{l}0.065 \\
-0.52\end{array}$ & $\begin{array}{l}-0.269 \\
(1.96)^{\star *}\end{array}$ & $\begin{array}{l}-0.425 \\
(2.80)^{\star * *}\end{array}$ & $\begin{array}{l}-0.031 \\
-0.26\end{array}$ & $\begin{array}{l}-0.335 \\
(2.45)^{\star *}\end{array}$ \\
\hline hhsplit & $\begin{array}{l}0.006 \\
-0.04\end{array}$ & $\begin{array}{l}0.088 \\
-0.75\end{array}$ & $\begin{array}{l}-0.086 \\
-0.67\end{array}$ & $\begin{array}{l}-0.02 \\
-0.14\end{array}$ & $\begin{array}{l}0.076 \\
-0.65\end{array}$ & $\begin{array}{l}-0.084 \\
-0.65\end{array}$ & $\begin{array}{l}0.072 \\
-0.51\end{array}$ & $\begin{array}{r}0.14 \\
-1.22\end{array}$ & $\begin{array}{l}-0.077 \\
-0.6\end{array}$ \\
\hline inherit & $\begin{array}{l}-0.193 \\
-1.3\end{array}$ & $\begin{array}{l}-0.115 \\
-0.94\end{array}$ & $\begin{array}{l}-0.294 \\
(2.24)^{* *}\end{array}$ & $\begin{array}{l}-0.214 \\
-1.44\end{array}$ & $\begin{array}{l}-0.115 \\
-0.94\end{array}$ & $\begin{array}{l}-0.307 \\
(2.34)^{* k}\end{array}$ & $\begin{array}{l}-0.214 \\
-1.48\end{array}$ & $\begin{array}{l}-0.14 \\
-1.17\end{array}$ & $\begin{array}{l}-0.294 \\
(2.25)^{* *}\end{array}$ \\
\hline Prop_GS & $\begin{array}{l}-0.338 \\
-0.68\end{array}$ & $\begin{array}{l}-0.247 \\
-0.64\end{array}$ & $\begin{array}{l}-0.837 \\
(190)^{*}\end{array}$ & $\begin{array}{l}-0.086 \\
-0.17\end{array}$ & $\begin{array}{l}-0.093 \\
-0.24\end{array}$ & $\begin{array}{l}-0.774 \\
(1.75)^{*}\end{array}$ & $\begin{array}{l}-0.531 \\
-1.08\end{array}$ & $\begin{array}{l}-0.23 \\
-0.61\end{array}$ & $\begin{array}{l}-0.843 \\
(193)^{\star}\end{array}$ \\
\hline Prop_IBV & $\begin{array}{l}0.189 \\
-0.64\end{array}$ & $\begin{array}{l}0.753 \\
(3.31)^{\star \star *}\end{array}$ & $\begin{array}{l}-0.365 \\
-1.35\end{array}$ & $\begin{array}{l}0.188 \\
-0.64\end{array}$ & $\begin{array}{c}0.734 \\
(3.21)^{\star \star \star}\end{array}$ & $\begin{array}{l}-0.381 \\
-1.42\end{array}$ & $\begin{array}{l}0.056 \\
-0.2\end{array}$ & $\begin{array}{c}0.663 \\
(3.01)^{\star \star \star}\end{array}$ & $\begin{array}{l}-0.421 \\
-1.57\end{array}$ \\
\hline $\mathrm{RC}$ & $\begin{array}{l}-0.297 \\
(2.25)^{\star *}\end{array}$ & $\begin{array}{l}-0.199 \\
(188)^{*}\end{array}$ & $\begin{array}{l}-0.097 \\
-0.84\end{array}$ & $\begin{array}{l}-0.261 \\
(1.97)^{\star *}\end{array}$ & $\begin{array}{l}-0.182 \\
(1.71)^{*}\end{array}$ & $\begin{array}{l}-0.093 \\
-0.8\end{array}$ & $\begin{array}{l}-0.294 \\
(2.29)^{\star \star}\end{array}$ & $\begin{array}{l}-0.18 \\
(1.75)^{*}\end{array}$ & $\begin{array}{l}-0.078 \\
-0.68\end{array}$ \\
\hline bus_d & $\begin{array}{l}-0.833 \\
(5.19)^{\star * \star}\end{array}$ & $\begin{array}{l}-0.317 \\
(2.71)^{\star * *}\end{array}$ & $\begin{array}{l}-0.151 \\
-1.17\end{array}$ & $\begin{array}{l}-0.825 \\
(5.08) * * \star\end{array}$ & $\begin{array}{l}-0.301 \\
(253)^{\star *}\end{array}$ & $\begin{array}{l}-0.135 \\
-1.04\end{array}$ & $\begin{array}{l}-0.846 \\
(5.46)^{\star \star \star}\end{array}$ & $\begin{array}{l}-0.339 \\
(3.00)^{\star \star *}\end{array}$ & $\begin{array}{l}-0.179 \\
-1.4\end{array}$ \\
\hline school_d & $\begin{array}{c}0.832 \\
(2.00)^{\star \star}\end{array}$ & $\begin{array}{c}0.425 \\
(177)^{*}\end{array}$ & $\begin{array}{l}-0.364 \\
-1.42\end{array}$ & $\begin{array}{l}0.584 \\
-1.44\end{array}$ & $\begin{array}{l}0.375 \\
-1.57\end{array}$ & $\begin{array}{l}-0.382 \\
-1.49\end{array}$ & $\begin{array}{c}0.841 \\
(2.07)^{\star \star}\end{array}$ & $\begin{array}{l}0.329 \\
-1.44\end{array}$ & $\begin{array}{l}-0.384 \\
-1.5\end{array}$ \\
\hline hospital_d & $\begin{array}{l}-1.073 \\
(5.34)^{\star \star \star}\end{array}$ & $\begin{array}{l}-0.65 \\
(4.65)^{\star * *}\end{array}$ & $\begin{array}{l}-0.261 \\
(1.75)^{*}\end{array}$ & $\begin{array}{l}-1.041 \\
(5.15)^{\star \star \star}\end{array}$ & $\begin{array}{l}-0.616 \\
(4.37)^{\star \star *}\end{array}$ & $\begin{array}{l}-0.237 \\
-1.58\end{array}$ & $\begin{array}{l}-1.035 \\
(5.29)^{\star \star *}\end{array}$ & $\begin{array}{l}-0.602 \\
(4.44)^{\star \star \star *}\end{array}$ & $\begin{array}{l}-0.267 \\
(1.79)^{*}\end{array}$ \\
\hline financial_d & $\begin{array}{c}0.373 \\
(2.39)^{\star *}\end{array}$ & $\begin{array}{l}0.439 \\
(3.54)^{\star \star \star}\end{array}$ & $\begin{array}{l}0.121 \\
-0.91\end{array}$ & $\begin{array}{c}0.401 \\
(2.54)^{\star \star}\end{array}$ & $\begin{array}{c}0.486 \\
(3.85)^{\star \star \star *}\end{array}$ & $\begin{array}{l}0.132 \\
-0.99\end{array}$ & $\begin{array}{c}0.257 \\
(170)^{*}\end{array}$ & $\begin{array}{c}0.288 \\
(241)^{\star *}\end{array}$ & $\begin{array}{l}0.054 \\
-0.41\end{array}$ \\
\hline Pubtab_d & $\begin{array}{l}0.153 \\
-0.79\end{array}$ & $\begin{array}{l}0.233 \\
-1.59\end{array}$ & $\begin{array}{l}0.116 \\
-0.69\end{array}$ & $\begin{array}{c}0.118 \\
-0.61\end{array}$ & $\begin{array}{l}0.197 \\
-1.35\end{array}$ & $\begin{array}{l}0.083 \\
-0.5\end{array}$ & $\begin{array}{l}0.108 \\
-0.56\end{array}$ & $\begin{array}{l}0.193 \\
-1.34\end{array}$ & $\begin{array}{l}0.099 \\
-0.6\end{array}$ \\
\hline Constant & $\begin{array}{l}-2.99 \\
(2.56)^{\star \star}\end{array}$ & $\begin{array}{l}-4.503 \\
(4.81)^{\star \star \star}\end{array}$ & $\begin{array}{l}-1.185 \\
-1.14\end{array}$ & $\begin{array}{l}-4.4 \\
(3.74)^{\star \star \star}\end{array}$ & $\begin{array}{l}-5.573 \\
(5.88)^{\star \star \star}\end{array}$ & $\begin{array}{l}-1.385 \\
-1.33\end{array}$ & $\begin{array}{l}-2.044 \\
(1.80)^{\star}\end{array}$ & $\begin{array}{l}-3.6 \\
(3.98)^{\star \star \star}\end{array}$ & $\begin{array}{l}-0.795 \\
-0.77\end{array}$ \\
\hline Observations & 3,782 & 3,782 & 3,782 & 3,782 & 3,782 & 3,782 & 3,782 & 3,782 & 3,782 \\
\hline $\begin{array}{l}\text { Pseudo R2 } \\
\text { Joint } \\
\text { significance }\end{array}$ & & $\begin{array}{c}\quad 0.25 \\
\text { LR chi2(111) } \\
=2255.68\end{array}$ & & & $\begin{aligned} & 0.25 \\
\text { LR chi2(111) } & =2286.03\end{aligned}$ & & & $\begin{array}{c}\quad 0.23 \\
\text { LR chi2(111) } \\
=2070.76\end{array}$ & \\
\hline
\end{tabular}

z-statistics in parentheses

* significant at $10 \%$; ** significant at $5 \%$; ** significant at $1 \%$

Source: REDS 1999 and 2006 
Figure1. Distribution of rural households by the estimated VEP

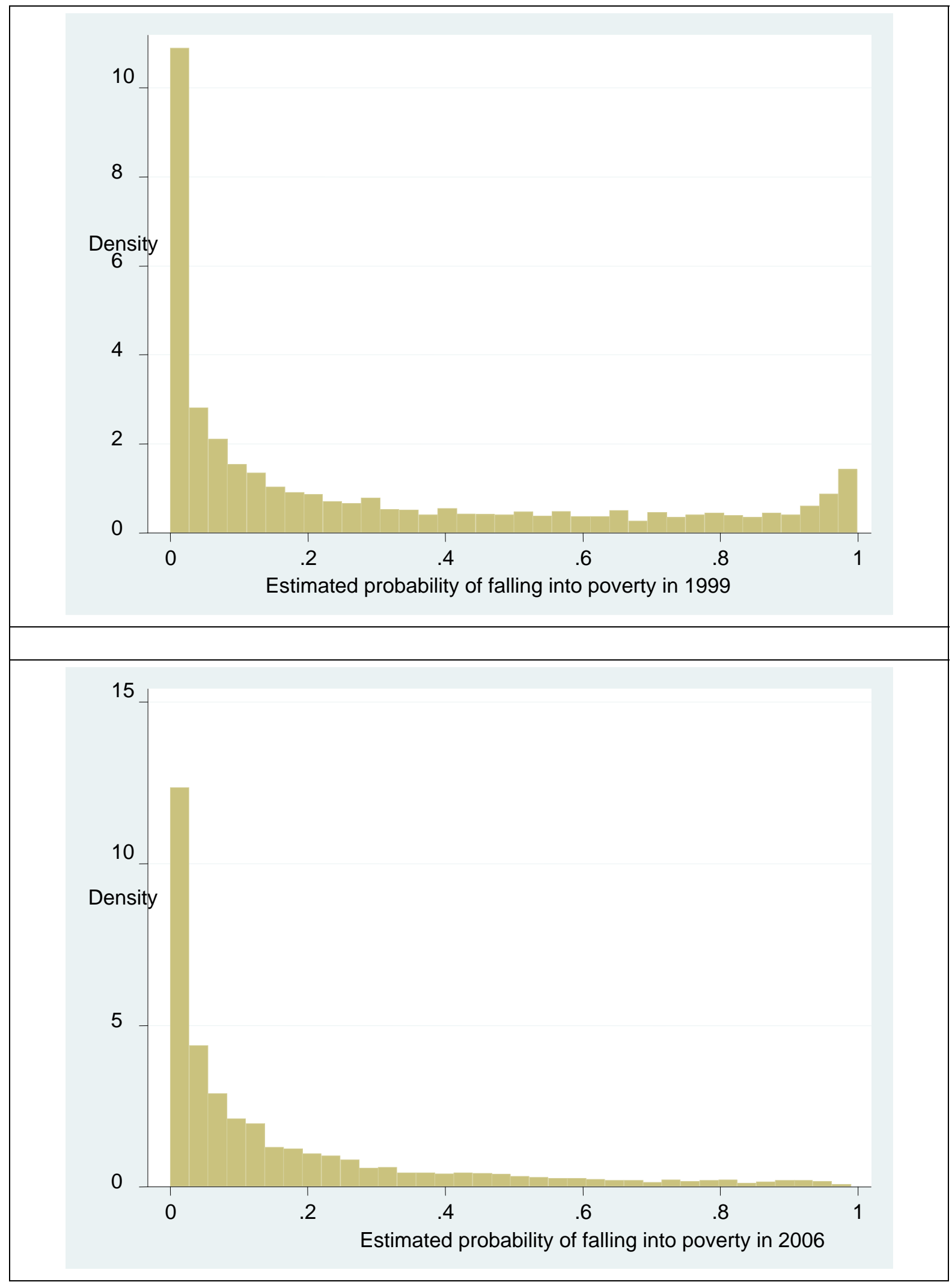

Source: REDS 1999 and 2006 
Figure2. Selective result from determinants of vulnerability (Quantile regression)

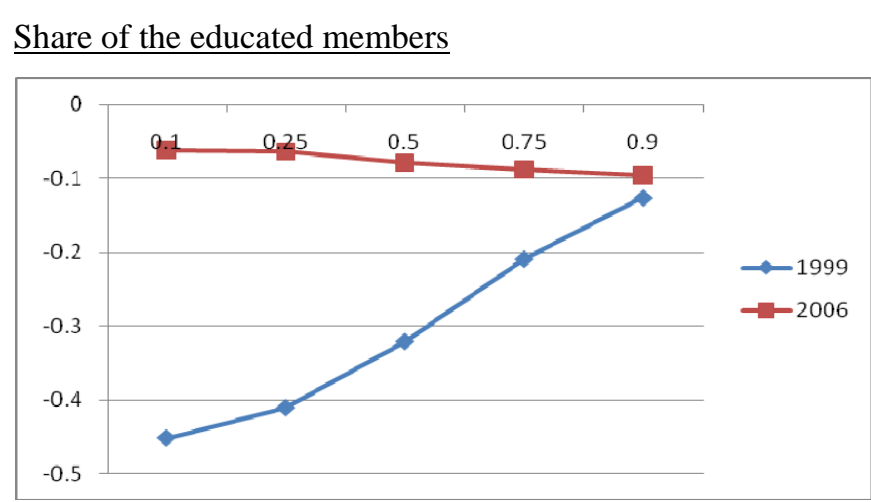

Female share
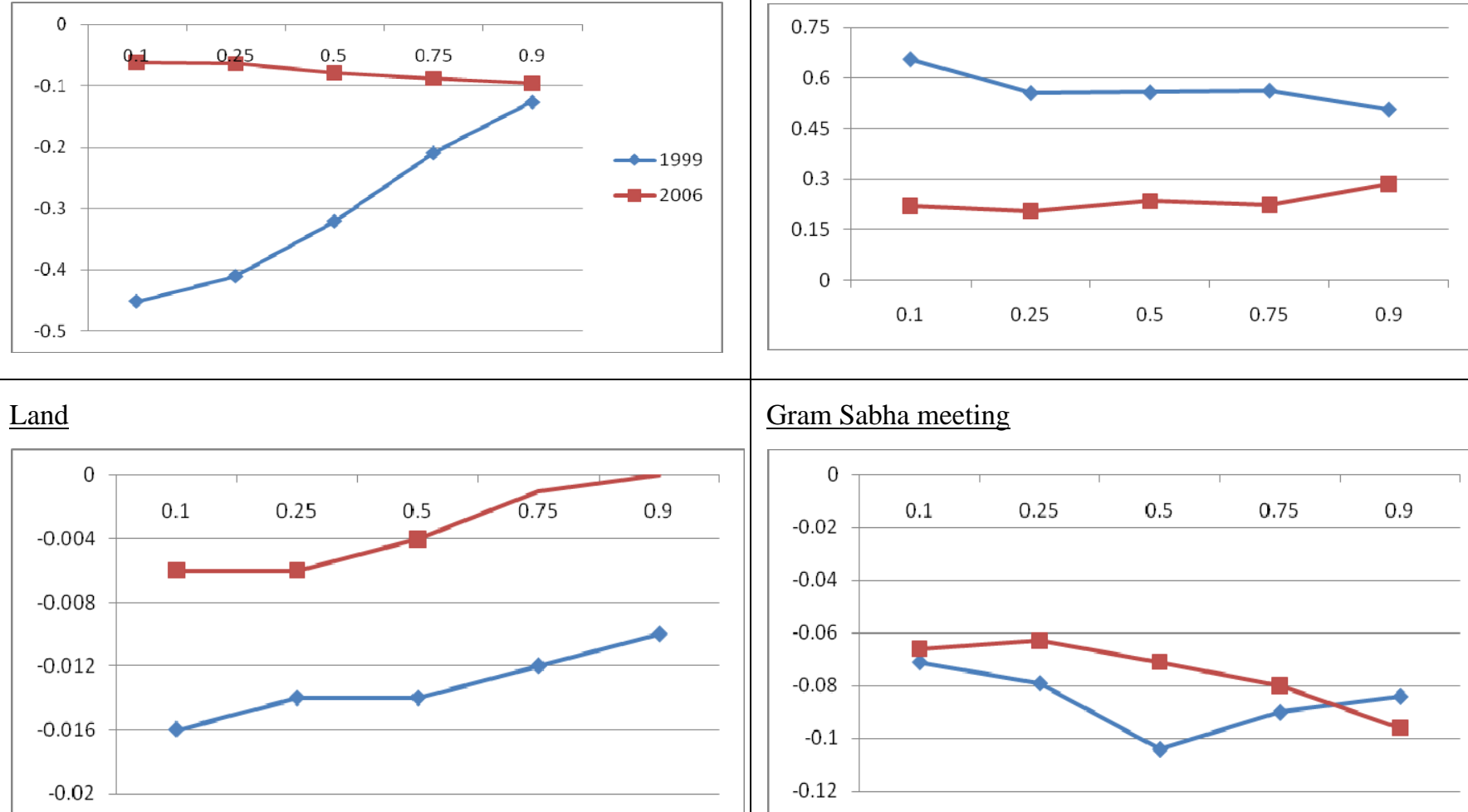

\section{Gram Sabha meeting}
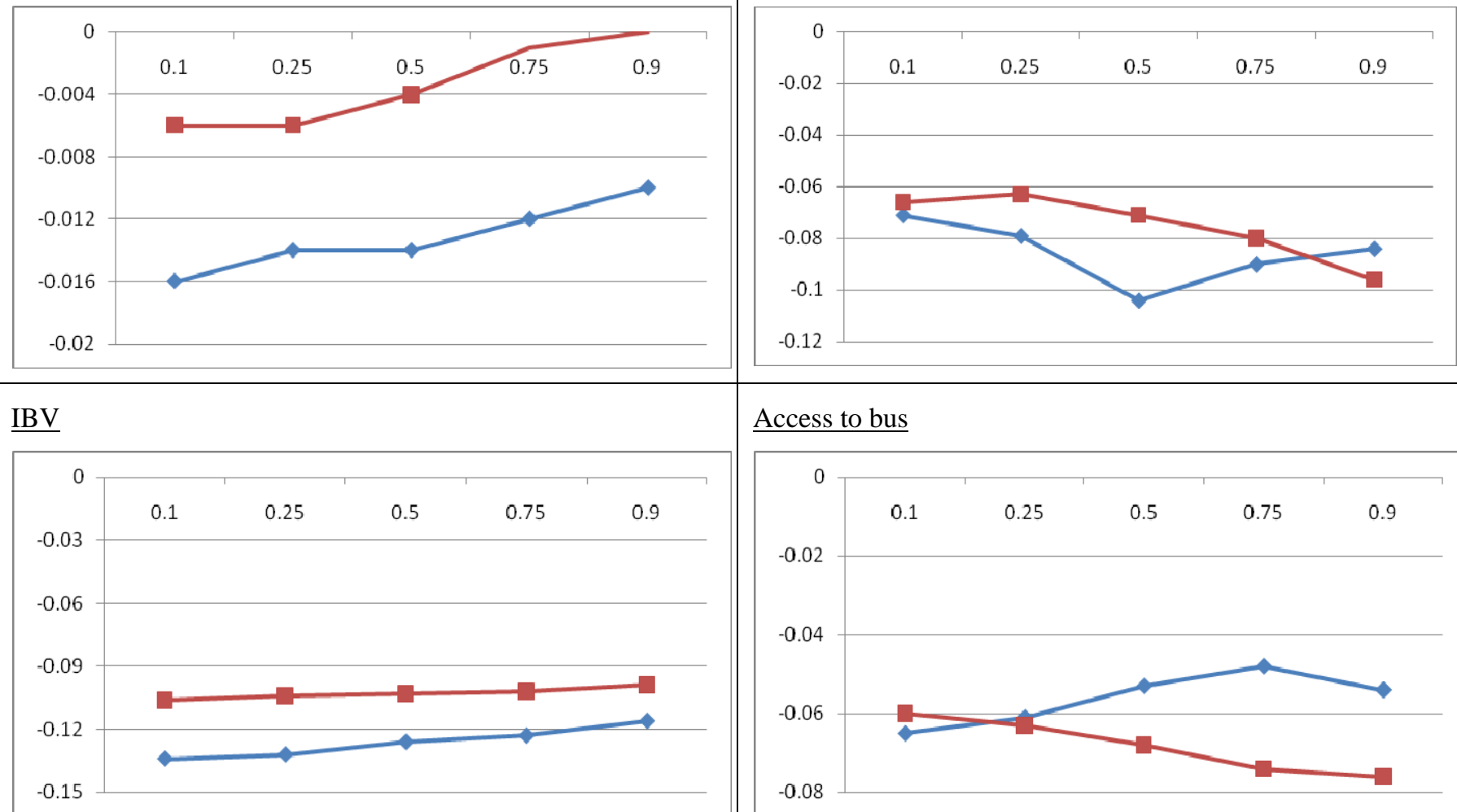

Access to bus

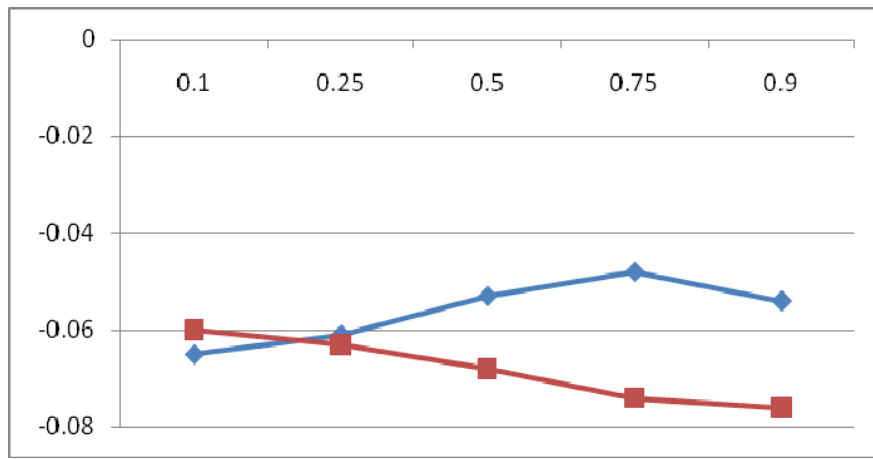

\section{Access to school}

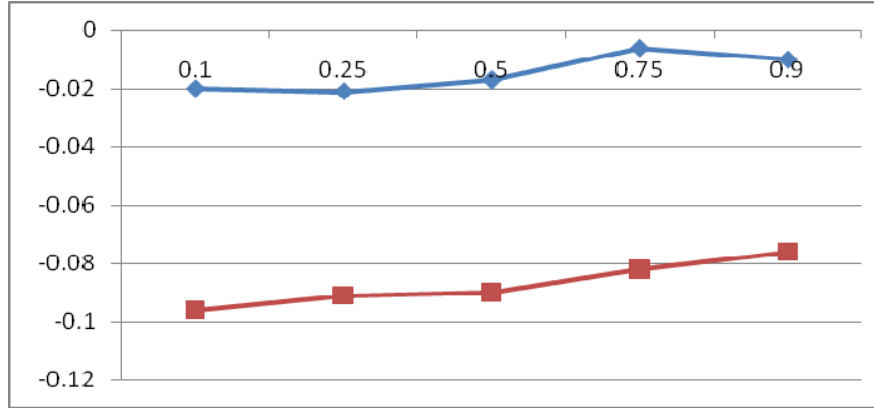

\section{Access to hospital}

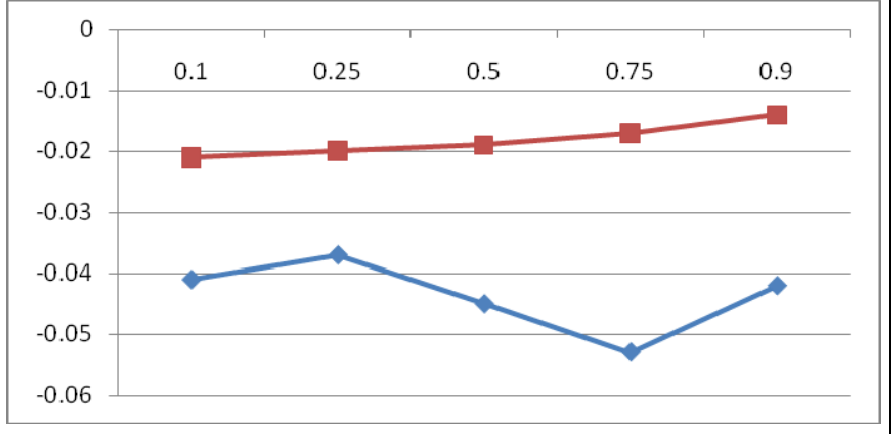

No marker in the line (e.g. $75^{\text {th }}$ percentile in the access to school in 1999) indicates that the coefficient of the variable in corresponding percentile is insignificant.

Source: REDS 1999 and 2006 
Appendix: Table A1 Simultaneous quantile regression with bootstrap 1000 replications

\begin{tabular}{|c|c|c|c|c|c|c|c|c|c|c|}
\hline & \multicolumn{5}{|c|}{ Dept. variable: VEP in 1999} & \multicolumn{5}{|c|}{ Dept. variable: VEP in 2006} \\
\hline & 0.1 & 0.25 & 0.5 & 0.75 & 0.9 & 0.1 & 0.25 & 0.5 & 0.75 & 0.9 \\
\hline \multirow[t]{2}{*}{ fhead } & 0.015 & 0.014 & 0.008 & -0.025 & -0.032 & -0.011 & -0.013 & -0.017 & -0.033 & -0.036 \\
\hline & $(2.79)^{\star k \star}$ & $(2.43)^{\star \star}$ & $(1.12)$ & $(2.88)^{\star k *}$ & $(3.25)^{\star \star \star}$ & $(4.72)^{\star \star \star}$ & $(5.04)^{\star \star *}$ & $(5.70)^{\star \star k}$ & $(7.22)^{\star k \star}$ & $(4.11)^{\star \star *}$ \\
\hline \multirow[t]{2}{*}{ Age_head } & 0.009 & 0.008 & 0.009 & 0.01 & 0.01 & -0.002 & -0.002 & -0.002 & -0.004 & -0.004 \\
\hline & $(12.04)^{\star \star \star}$ & $(12.29)^{* k *}$ & $(10.76)^{\star \star *}$ & $(10.42)^{\star \star \star *}$ & $(7.16)^{\star \star \star}$ & $(4.29)^{\star \star \star *}$ & $(4.72)^{\star \star k}$ & $(4.98)^{\star \star \star}$ & $(4.51)^{\star \star * k}$ & $(3.30)^{\star \star \star}$ \\
\hline \multirow[t]{2}{*}{ (Age_head)2 } & 0 & 0 & 0 & 0 & 0 & 0 & 0 & 0 & 0 & 0 \\
\hline & $(10.29)^{\star \star \star}$ & $(10.20)^{\star \star \star}$ & $(9.16)^{\star \star *}$ & $(9.09)^{\star \star *}$ & $(6.32)^{\star \star \star}$ & $(1.17)$ & & $(0.49)$ & $(180)^{*}$ & (1.34) \\
\hline \multirow[t]{2}{*}{ seconedushare } & -0.452 & -0.411 & -0.321 & -0.209 & -0.126 & -0.062 & -0.064 & -0.079 & -0.088 & -0.096 \\
\hline & $(23.59)^{\star \star \star \star}$ & $(25.99)^{\star \star \star *}$ & $(18.93)^{\star \star * *}$ & $(11.83)^{\star \star \star *}$ & $(6.46)^{\star \star \star *}$ & $(16.40)^{\star * *}$ & $(19.71)^{\star \star \star \star}$ & $(15.28)^{\star \star \star}$ & $(13.89)^{\star \star \star *}$ & $(8.96)^{\star \star \star *}$ \\
\hline \multirow[t]{2}{*}{ femaleshare } & 0.656 & 0.556 & 0.558 & 0.563 & 0.507 & 0.221 & 0.206 & 0.235 & 0.224 & 0.286 \\
\hline & $(13.37)^{\star \star \star k}$ & $(12.50)^{\star \star \star}$ & $(10.57)^{\star \star \star *}$ & $(9.73)^{\star \star \star}$ & $(5.43)^{\star \star \star}$ & $(10.03)^{\star \star k}$ & $(9.47)^{\star \star \star k}$ & $(7.89)^{\star \star \star}$ & $(6.25)^{\star \star \star *}$ & $(5.79)^{\star \star k *}$ \\
\hline \multirow[t]{2}{*}{ femaleshare2 } & -0.567 & -0.481 & -0.495 & -0.5 & -0.437 & -0.182 & -0.171 & -0.2 & -0.178 & -0.239 \\
\hline & $(12.42)^{\star k \star}$ & $(11.58)^{\star k \star}$ & $(10.02)^{\star \star \star}$ & $(9.22)^{\star \star k}$ & $(4.83)^{\star \star \star}$ & $(8.94)^{\star \star \star}$ & $(8.62)^{\star k \star k}$ & $(7.60)^{\star \star k}$ & $(5.50)^{\star \star k}$ & $(5.10)^{\star \star \star}$ \\
\hline \multirow[t]{2}{*}{ dependency } & 0.103 & 0.11 & 0.11 & 0.131 & 0.123 & 0.097 & 0.107 & 0.108 & 0.105 & 0.096 \\
\hline & $(13.38)^{\star \star \star}$ & $(13.57)^{\star \star \star}$ & $(9.82)^{* * *}$ & $(10.63)^{\star \star \star}$ & $(7.83)^{\star \star \star}$ & $(17.58)^{\star \star \star}$ & $(2151)^{\star \star \star}$ & $(18.28)^{\star \star \star}$ & $(13.82)^{\star \star \star \star}$ & $(6.88)^{\star \star \star}$ \\
\hline \multirow[t]{2}{*}{ Tot_land } & -0.016 & -0.014 & -0.014 & -0.012 & -0.01 & -0.006 & -0.006 & -0.004 & -0.001 & 0 \\
\hline & $(10.80)^{\star \star \star}$ & $(8.12)^{\star \star \star \star}$ & $(6.86)^{\star \star \star}$ & $(7.74)^{\star \star k}$ & $(6.16)^{\star \star \star}$ & $(7.20)^{\star \star \star}$ & $(5.39)^{\star k *}$ & $(2.32)^{\star *}$ & $(0.57)$ & $(0.08)$ \\
\hline \multirow[t]{2}{*}{ (Tot_land)2 } & 0 & 0 & 0 & 0 & 0 & 0 & 0 & 0 & 0 & 0 \\
\hline & (1.44) & $(0.95)$ & $(241)^{\star *}$ & $(3.53)^{\star \star k}$ & $(2.60)^{\star \star \star}$ & $(0.52)$ & $(0.43)$ & $(0.21)$ & $(0.05)$ & $(0.02)$ \\
\hline \multirow[t]{2}{*}{ land_irrshare } & -0.112 & -0.104 & -0.096 & -0.103 & -0.12 & -0.091 & -0.092 & -0.096 & -0.099 & -0.101 \\
\hline & $(23.98)^{\star \star k}$ & $(25.52)^{\star \star \star}$ & $(20.95)^{\star \star *}$ & $(20.96)^{\star \star \star}$ & $(19.34)^{\star \star \star}$ & $(26.66)^{\star k \star}$ & $(30.48)^{\star \star \star}$ & $(27.65)^{\star \star \star}$ & $(25.57)^{\star \star \star}$ & $(17.01)^{\star \star \star}$ \\
\hline \multirow[t]{2}{*}{ hhsplit } & -0.034 & -0.034 & -0.032 & -0.03 & -0.035 & -0.008 & -0.012 & -0.014 & -0.018 & -0.021 \\
\hline & $(12.86)^{\star \star *}$ & $(12.66)^{\star \star \star}$ & $(8.21)^{\star \star \star *}$ & $(8.50)^{\star \star \star *}$ & $(7.28)^{\star \star \star}$ & $(4.94)^{\star \star * *}$ & $(7.27)^{\star * *}$ & $(6.33)^{\star \star \star}$ & $(5.12)^{\star k \star}$ & $(4.11)^{\star * *}$ \\
\hline \multirow[t]{2}{*}{ inherit } & 0.034 & 0.024 & 0 & -0.014 & -0.009 & -0.021 & -0.024 & -0.027 & -0.031 & -0.037 \\
\hline & $(1174)^{\star k \star}$ & $(5.70)^{* k k}$ & $(0.05)$ & $(1.67)^{*}$ & $(0.68)$ & $(13.05)^{\star \star \star}$ & $(13.52)^{\star \star \star}$ & $(10.88)^{\star \star k}$ & $(8.94)^{k k k}$ & $(7.33)^{\star \star \star}$ \\
\hline \multirow[t]{2}{*}{ Prop_GS } & -0.071 & -0.079 & -0.104 & -0.09 & -0.084 & -0.066 & -0.063 & -0.071 & -0.08 & -0.096 \\
\hline & $(5.59)^{\star \star \star *}$ & $(6.92)^{\star \star \star *}$ & $(6.89)^{\star \star \star}$ & $(6.00)^{\star \star * k}$ & $(4.88)^{\star \star \star}$ & $(9.08)^{\star \star \star *}$ & $(9.70)^{\star \star \star *}$ & $(7.00)^{\star \star \star}$ & $(7.29)^{\star \star \star \star ~}$ & $(5.30)^{\star \star \star *}$ \\
\hline \multirow[t]{2}{*}{ Prop_IBV } & -0.134 & -0.132 & -0.126 & -0.123 & -0.116 & -0.106 & -0.104 & -0.103 & -0.102 & -0.099 \\
\hline & $(15.65)^{\star \star \star}$ & $(17.21)^{\star \star \star}$ & $(13.98)^{\star \star \star *}$ & $(13.88)^{\star \star \star}$ & $(10.61)^{\star \star \star}$ & $(20.65)^{\star \star *}$ & $(22.76)^{\star \star \star}$ & $(20.15)^{\star \star \star}$ & $(15.40)^{\star k \star}$ & $(10.03)^{\star \star \star}$ \\
\hline \multirow[t]{2}{*}{$\mathrm{RC}$} & -0.004 & -0.002 & -0.002 & -0.009 & -0.016 & -0.024 & -0.024 & -0.024 & -0.026 & -0.024 \\
\hline & $(172)^{*}$ & $(0.80)$ & $(0.61)$ & $(191)^{*}$ & $(2.92)^{\star \star \star}$ & $(17.58)^{\star k \star}$ & $(16.72)^{\star \star \star}$ & $(1169)^{\star \star \star}$ & $(8.66)^{* k *}$ & $(5.43)^{\star \star \star}$ \\
\hline \multirow[t]{2}{*}{ bus_d } & -0.065 & -0.061 & -0.053 & -0.048 & -0.054 & -0.06 & -0.063 & -0.068 & -0.074 & -0.076 \\
\hline & $(16.16)^{\star \star \star}$ & $(15.31)^{\star \star \star}$ & $(10.73)^{\star \star \star ~}$ & $(11.92)^{\star \star \star}$ & $(10.04)^{* \star *}$ & $(2224)^{\star \star \star *}$ & $(27.02)^{\star \star \star ~}$ & $(24.87)^{\star \star \star}$ & $(22.17)^{\star \star \star}$ & $(15.26)^{\star \star \star}$ \\
\hline \multirow[t]{2}{*}{ school_d } & -0.02 & -0.021 & -0.017 & -0.006 & -0.01 & -0.096 & -0.091 & -0.09 & -0.082 & -0.076 \\
\hline & $(9.89)^{\star k \star k}$ & $(8.02)^{\star \star \star k}$ & $(4.41)^{\star \star \star}$ & $(1.69)^{*}$ & $(2.05)^{\star \star}$ & $(20.04)^{\star * *}$ & $(27.00)^{\star \star \star}$ & $(18.38)^{\star \star \star *}$ & $(12.91)^{\star \star \star}$ & $(7.50)^{\star \star \star *}$ \\
\hline \multirow[t]{2}{*}{ hospital_d } & -0.041 & -0.037 & -0.045 & -0.053 & -0.042 & -0.021 & -0.02 & -0.019 & -0.017 & -0.014 \\
\hline & $(12.08)^{\star \star \star}$ & $(9.48)^{\star \star k \kappa}$ & $(7.65)^{\star \star \star *}$ & $(6.92)^{\star * k}$ & $(5.55)^{\star \star \star}$ & $(12.46)^{\star \star \star *}$ & $(1144)^{\star \star *}$ & $(7.18)^{\star \star \star}$ & $(4.85)^{* k \star k}$ & $(2.87)^{\star \star k *}$ \\
\hline financial_d & 0.004 & 0.006 & 0.001 & -0.004 & -0.002 & -0.005 & -0.005 & -0.007 & -0.011 & -0.017 \\
\hline & $(168)^{*}$ & $(2.11)^{\star \star}$ & $(0.19)$ & (1.10) & $(0.36)$ & $(3.48)^{\star \star \star}$ & $(2.67)^{\star \star k *}$ & $(286)^{\star \star k}$ & $(3.15)^{\star \star \star *}$ & $(3.44)^{\star \star \star}$ \\
\hline Pubtab_d & -0.015 & -0.016 & -0.016 & -0.016 & -0.024 & -0.017 & -0.021 & -0.019 & -0.018 & -0.022 \\
\hline & $(5.49)^{\star k \star k}$ & $(4.66)^{\star \star k}$ & $(4.26)^{\star * *}$ & $(3.75)^{\star \star \star}$ & $(3.76)^{\star \star \star}$ & $(9.98)^{\star \star k}$ & $(1131)^{\star \star \star}$ & $(8.31)^{\star \star \star}$ & $(5.06)^{k k t}$ & $(3.78)^{\star \star \star}$ \\
\hline Constant & -0.198 & -0.155 & -0.146 & -0.164 & -0.095 & 0.489 & 0.535 & 0.655 & 0.835 & 0.971 \\
\hline & $(8.92)$ & $(7.40)$ & (5.65) & (5.62) & $(1.95)$ & $(28.43)$ & $(30.76)$ & $(27.91)$ & $(28.87)$ & $(22.14)$ \\
\hline Observations & 4743 & 4743 & 4743 & 4743 & 4743 & 4532 & 4532 & 4532 & 4532 & 4532 \\
\hline Pseudo R2 & 0.47 & 0.56 & 0.66 & 0.73 & 0.73 & 0.47 & 0.55 & 0.64 & 0.72 & 0.76 \\
\hline Joint significance & & & $4708)=950$ & & & & $F(180$ & $495)=494.5$ & & \\
\hline Prob $>F$ & & & 0.0000 & & & & & 0.0000 & & \\
\hline
\end{tabular}

t statistics in parentheses

* significant at 10\%; ** significant at 5\%; *** significant at $1 \%$

Source: REDS 1999 and 2006 
Appendix: Table A2. Summary statistics

\begin{tabular}{|c|c|c|c|c|c|c|c|c|c|}
\hline \multirow{2}{*}{ Variable } & \multirow{2}{*}{ Description } & \multicolumn{4}{|c|}{1999} & \multicolumn{4}{|c|}{2006} \\
\hline & & Mean & Std. Dev. & Min & Max & Mean & Std. Dev. & Min & Max \\
\hline \multicolumn{10}{|c|}{ Household characteristic } \\
\hline Ipcex & log (per capita household income) & 8.561 & 0.463 & 6.998 & 10.825 & 8.642 & 0.547 & 6.494 & 11.394 \\
\hline fhead & 1 if a household head if female, othervise 0 & 0.055 & 0.229 & 0 & 1 & 0.100 & 0.300 & 0 & 1 \\
\hline age & Age of a household head & 49.406 & 13.725 & 16 & 96 & 51.151 & 13.337 & 23 & 103 \\
\hline seconedu & Share of members with secondary or higher education to total members & 0.169 & 0.233 & 0 & 1 & 0.751 & 0.243 & 0 & 1 \\
\hline femaleshare & Share of female members to total members & 0.474 & 0.153 & 0 & 1 & 0.495 & 0.164 & 0 & 1 \\
\hline dependency & Share of household members aged below 14 or above 65 & 0.442 & 0.174 & 0 & 1 & 0.458 & 0.194 & 0 & 1 \\
\hline Tot_land & Size of total owned land & 3.903 & 6.883 & 0 & 200 & 1.627 & 4.416 & 0 & 200 \\
\hline land_irrshare & the ratio of the irrigated land to total land size & 0.401 & 0.465 & 0 & 1 & 0.353 & 0.457 & 0 & 1 \\
\hline hhsplit & 1 if a household split, otherwise 0 & 0.453 & 0.498 & 0 & 1 & 0.345 & 0.476 & 0 & 1 \\
\hline inherit & 1 if women inherit land, otherwise 0 & 0.049 & 0.217 & 0 & 1 & 0.330 & 0.470 & 0 & 1 \\
\hline prop_GS & Share of members participated in Gram Sabha meetings & 0.065 & 0.147 & 0 & 1 & 0.084 & 0.160 & 0 & 1 \\
\hline prop_IBV & Share of members voted based on identify & 0.164 & 0.230 & 0 & 1 & 0.210 & 0.268 & 0 & 1 \\
\hline \multicolumn{10}{|c|}{ Village characteristic } \\
\hline $\mathrm{RC}$ & 1 if gender of a pradhan changed, otherwise 0 & 0.373 & 0.485 & 0 & 1 & 0.475 & 0.500 & 0 & 1 \\
\hline bus_d & 1 if a village has access to bus, othemise 0 & 0.439 & 0.497 & 0 & 1 & 0.477 & 0.501 & 0 & 1 \\
\hline school_d & 1 if a village has access to school, otherwise 0 & 0.598 & 0.491 & 0 & 1 & 0.941 & 0.236 & 0 & 1 \\
\hline hospital_d & 1 if a village has access to public hospital, othervise 0 & 0.191 & 0.394 & 0 & 1 & 0.315 & 0.466 & 0 & 1 \\
\hline financial_d & 1 if a village has access to public financial institution, othemise 0 & 0.535 & 0.500 & 0 & 1 & 0.563 & 0.497 & 0 & 1 \\
\hline pubtab_d & 1 if a village has access to public tab, othervise 0 & 0.506 & 0.501 & 0 & 1 & 0.559 & 0.498 & 0 & 1 \\
\hline
\end{tabular}

Source: REDS 1999 and 2006 